\title{
Epidemiology of bovine tuberculosis in Mexico, bordering the United States, at establishment of controlling strategies
}

\author{
[Epidemiologia da tuberculose bovina na fronteira do México com os Estados Unidos, \\ por ocasião do estabelecimento das estratégias de controle] \\ C. Enríquez-Cruz ${ }^{1}$, N.I. Cruz-Hernández ${ }^{1}$, J.L. Zertuche-Rodríguez ${ }^{1}$, J.L. Uriegas-García ${ }^{2}$, \\ J.E. Toscano-Ruiz ${ }^{2}$, G.H. Flores-Gutiérrez ${ }^{3 *}$ \\ ${ }^{1}$ Facultad de Medicina Veterinaria y Zootecnia "Dr. Norberto Treviño Zapata" \\ Universidad Autónoma de Tamaulipas - Victoria, Tamaulipas, México \\ ${ }^{2}$ Comité para el Fomento y Protección Pecuaria del Estado de Tamaulipas - Victoria, Tamaulipas, México \\ ${ }^{3}$ Unidad Académica Multidisciplinaria Reynosa-Aztlán \\ Universidad Autónoma de Tamaulipas - Reynosa, Tamaulipas, México
}

\begin{abstract}
A case-control study was carried out for determining epidemiological patterns at the beginning of the Mexican campaign against bovine tuberculosis (BTB) in the State of Tamaulipas, Mexico, bordering the United States of America. From January 1995 to March 1998, 599 direct tissue smears of cattle from routine slaughterhouse inspection were analyzed for the presence of Mycobacterium bovis acid-fastness with Ziehl-Neelsen stain. BTB status was associated with year of diagnosis, age, breed, geographical origin of cattle, and type of slaughterhouse using the odds ratio (OR) (95\% confidence level). The prevalence at slaughterhouse surveillance was $15.36 \%$, which was considerably higher in 1995 (41.38\%, OR=5.78, $\mathrm{P}<0.0001)$, in comparison with $8.09 \%, 14.42 \%$, and $10.14 \%$ for the years 1996,1997 , and 1998, respectively. BTB was associated with cattle from the State of Tamaulipas $(19.73 \%, \mathrm{OR}=4.438, \mathrm{P}=0.01)$, adult cattle $(19.13 \%$, $\mathrm{OR}=2.19, \mathrm{P}<0.0001)$, Bos taurus $(22.54 \%, \mathrm{OR}=2.135, \mathrm{P}<0.0001)$ and $B$. taurus $\mathrm{x}$ B. indicus cross bred animals $(29.31 \%, 2.769, \mathrm{P}<0.0001)$, and cattle slaughtered at federal inspected abattoir $(17.58 \%, \mathrm{OR}=1.23, \mathrm{P}<0.0001)$.
\end{abstract}

Keywords: bovine tuberculosis, United States/Mexico border, epidemiologic control

\section{RESUMO}

O estudo foi realizado para determinar os padrões epidemiológicos no início da campanha mexicana contra a tuberculose bovina (BTB), no Estado de Tamaulipas, fronteira com os Estados Unidos da América. De janeiro de 1995 a março de 1998, 599 amostras de tecidos bovinos, obtidas em inspeção de rotina em abatedouros, foram analisadas para a presença de Mycobacterium bovis, fixadas em corante Ziehl-Neelsen. O status BTB foi associado ao ano do diagnóstico, idade, raça e origem geográfica do bovino utilizando a razão de probabilidade (OR) (com intervalo de confiança de 95\%). A prevalência no abatedouro sob inspeção foi de 15,36\%, consideravelmente maior em 1995 (41,38\%, OR=5,78), P<0,0001) em relação a 8,09\%, 4,42\% e 10,14\% para 1996, 1997 e 1998, respectivamente. Houve associação entre BTB e animais provenientes do estado de Tamaulipas $(19,73 \% ; O R=0.438 ; P=0.01)$, idade adulta $(19,13 \% ; O R=2,19 ; P<0,0001)$, Bos taurus $(22,54 \% ; O R=2,135 ; P<0,0001)$ e cruzamentos B. taurus $x$ B. indicus $(29,31 \% ; 2,769 ; P<0,0001)$, e animais abatidos em abatedouros federais inspecionados $(17,58 \%$; OR=1,23; $P<0,0001)$.

Palavras-chave: tuberculose bovina, fronteira Estados Unidos/México, controle epidemiológico

\section{INTRODUCTION}

Bovine tuberculosis (BTB) is a chronic and emaciating infectious disease caused by
Mycobacterium bovis, which affects domesticated and wild mammals (O'Brien et al., 2006; Proaño-Perez et al., 2006; Berg et al., 2009). In addition, this disease constitutes a public health problem, affecting people that have

Recebido em 27 de outubro de 2009

Aceito em 10 de agosto de 2010

*Autor para correspondência (corresponding author)

E-mail: ghflores@uat.edu.mx 
close contact with infected cattle (Cousins, 2001; Proaño-Perez et al., 2006).

The World Organization for Animal Health has classified BTB into their List B; i.e., those transmissible disease with socio-economic and/or public health implications and that is significant for the international trade of live animals and their products. For livestock production, BTB is cause of high economic losses due to reduced production, culling of infected animals and condemnation of carcasses (Diguimbaye-Djaibé et al., 2006; Proaño-Perez et al., 2006; Elias et al., 2008). Furthermore, the disease constitutes a barrier for the international trade of livestock when is prevalent in a region (Cousins, 2001; Demelash et al., 2009). In Mexico, the economic losses due to the presence of BTB could be calculated in the order of US\$ 450 million, as consequence of a limited exportation of livestock to the United States of America (DOF, 1996).

As a consequence, several countries have instigated programs focused on controlling and eradicating BTB (Cousins, 2001). The main strategy of these programs consists in using the tuberculin skin testing prior to cattle movement, after which the positive animals are segregated and/or slaughtered (Diguimbaye-Djaibé et al., 2006; Proaño-Perez et al., 2006; Ameni et al., 2007; Tadayon et al., 2008). In Mexico, the campaign against BTB was officially implemented in 1996, and comprises the mandatory execution of activities concerning the control, eradication, and accreditation of freestatus of the disease; i.e., diagnosis of BTB using the intradermal tuberculin skin and/or histological and microbiological techniques, slaughtering of positive cattle, movement restrictions of livestock from prevalent to free areas, and a permanent inspection and surveillance system in both, herds and slaughterhouses (DOF, 1996). These activities have been carried out despite several years ago Mexico has been considered as a low BTB prevalent country (Roadhouse, 1911).

Although the success of strategies for controlling and eradicating BTB and the consequential achievement of a free-status certification depend upon the implementation of an effective surveillance policy (Elias et al., 2008; Ngandolo et al., 2009), the information concerning the prevalence of the disease is scare or absent for developing countries (Ngandolo et al., 2009). Therefore, the objectives of this study was to determine some selected epidemiological patters associated with BTB and to evaluate the effectiveness of the test-and-slaughter policy at the first stages of the Mexican campaign against BTB, implemented in the State of Tamaulipas, Mexico.

\section{MATERIAL AND METHODS}

The State of Tamaulipas is located in Northeast Mexico, bordering the Lower Rio Grande Valley of Southeast Texas, in the United States of America. Livestock production, comprising both extensive and intensive systems, is one of the main economic activities for Tamaulipas, with an average bovine population of $1,300,000$ heads during the years in which the study was accomplished. This state occupies the third place of the country concerning exportation of cattle to the United States of America (SIAP, 2005). According their economical activities, Tamaulipas is classified into municipalities of the North, Centre, South, and Southwest; this classification was utilized for the statistical analysis of the generated information.

From January 1995 to March 1998, 599 cattle tissues and organs samples that presented BTBgross lesions were preserved in a $10 \%$ buffered formalin solution and referred to the Pathology Laboratory of the College of Veterinary Medicine at the Autonomous University of Tamaulipas, Mexico, as an official reference laboratory for the diagnosis of BTB. The samples included those of routine surveillance at slaughterhouses with suspect lesions and samples obtained from cattle that reacted positively to the comparative intradermal tuberculin skin test containing bovine and avian purified protein derivative products.

The laboratory confirmation of biological samples was carried out using histopathological techniques on organs and/or tissues samples, which were stained with Ziehl-Neelsen for the microscopic demonstration of the $M$. bovis acidfastness on tissue direct smears. These procedures are the officially established by the Mexican Federal Norm against BTB (DOF, 1996) and are in agreement with the techniques previously described (OIE, 2008). The epidemiological sensitivity and specificity of the 
aforementioned techniques are $98 \%$ and $87 \%$, and $90 \%$ and $97 \%$, respectively (Fitzgerald et al., 2000). However, when the diagnostic techniques were used in parallel, the epidemiological sensitivity and specificity values were $99.8 \%$ and $99.61 \%$, respectively, as calculated with the software Win Episcope 2.0 (Veterinary School, Zaragoza, Spain).

The main variables of the diagnosed cattle were classified in agreement with the year when the diagnosis was performed; the age of cattle, i.e., calf (up to 12 months of age), heifers/steers (from 12 to 24 months of age), and adult cattle (older than 24 months of age); breed, i.e., nondefined breed, Bos indicus, B. taurus, and $B$. taurus $\mathrm{X} B$. indicus (synthetic breeds); geographical origin; and type of abattoir where the animals were slaughtered; i.e., municipal or federal-inspected slaughterhouse.

In order to determine the prevalence of BTB, the population considered at risk was the total number of cattle in each one of the defined variables. Furthermore, the prevalence values were compared with the international trade data, i.e., exporting of live cattle to the United States of America, for assessing the effect of the Mexican campaign against BTB. In addition, the risk factors associated with BTB were determined by the odds ratio (OR) calculated for a stratified case-control study. The effect of confounding variable, i.e., age and breed of cattle, was avoided by pooling the factors with the Mantel-Haenszel estimators using Win Episcope 2.0 at a 95\% confidence level (AcostaGonzalez et al., 2009).

\section{RESULTS}

The range for the age of the diagnosed cattle was four to 192 months $(68.77 \pm 36.1$ months $)$. Concerning the breed of the diagnosed animals, the non-defined breed $(44.94 \%)$ predominated over the B. taurus, B. indicus, and B. taurus $\times$ B . indicus breeds, which represented $17.60 \%$, $26.59 \%$, and $10.86 \%$, respectively. The geographical origin was mostly from the State of Tamaulipas $(75.8 \%)$, but also there were animals from other Mexican states (Nuevo León, Coahuila, Veracruz, San Luis Potosí, and Chiapas) and from Texas, in the United States of America. The cattle were mainly slaughtered in municipal abattoirs $(71.1 \%)$, in contrast with the federal-inspected slaughterhouses $(28.9 \%)$.

The biological samples included in the study proceeded from cattle carcasses that showed suspected tuberculous lesions during the normal slaughtering process $(72.79 \%)$; another fraction of the biological samples were from slaughtered animals that previously were positive to the comparative intradermal tuberculin skin test $(27.21 \%)$. The samples referred for BTB diagnosis were mainly lymphatic nods, lungs, and liver (Table 1).

The overall prevalence of BTB at the slaughterhouse surveillance was $15.36 \%$, which was considerably higher $(41.38 \%)$ in 1995 , in comparison with $8.09 \%, 14.42 \%$, and $10.14 \%$ for the years 1996, 1997, and 1998, respectively. However, the true prevalence was slightly lower when it was recalculated with Win Episcope 2.0 using the aforementioned values of $99.8 \%$ and $99.61 \%$ for epidemiological sensitivity and specificity, respectively, for parallel tests. The true prevalence values were as follows: overall prevalence $15.06 \%$; and $41.23 \%, 7.75 \%$, $14.11 \%$, and $9.8 \%$, respectively, for 1995,1996 , 1997, and 1998 (Table 2). In addition, the prevalence of the analyzed years was strongly related with the number of cattle heads that were exported from Tamaulipas to the United States of America $(r=0.968)$, with a significantly decrement in the 1995 before the beginning of the official campaign. However, this indicator had a gradual increase while the prevalence was lowering in the subsequent years (Figure 1).

All positive animals were those with geographical origin from Mexican states, for which the prevalences were $19.73 \%, 8.33 \%$, and $14.29 \%$ for the states of Tamaulipas, Nuevo León, and Coahuila, respectively. All analyzed cattle from the Mexican states of Veracruz, San Luis Potosí, and Chiapas were negative for BTB and also the cattle from Texas. In the four-year period of the study, the higher prevalence values were for adult cattle $(19.13 \%)$, B. taurus, $B$. taurus x B. indicus breeds $(22.54 \%$ and $29.31 \%$, respectively), and for the cattle slaughtered in federal inspected abattoirs $(17.58 \%)$.

The higher prevalence of BTB was associated with 1995 as year of diagnosis $(\mathrm{OR}=5.78$; $\mathrm{P}<0.0001)$, adult cattle $(\mathrm{OR}=2.19 ; \mathrm{P}<0.0001), B$. 
taurus, and B. taurus $\mathrm{x} B$. indicus animals $(\mathrm{OR}=2.135$ and 2.769 , respectively; $\mathrm{P}<0.0001)$, which were from the State of Tamaulipas as geographical origin $(\mathrm{OR}=4.438 ; \mathrm{P}=0.01)$, and slaughtered at federal inspected abattoirs $(\mathrm{OR}=1.23 ; \mathrm{P}<0.0001)$ (Table 2$)$.

Table 1. Biological samples collected at routine slaughterhouse inspection for the diagnosis of bovine tuberculosis in cattle from the Northeast of Mexico, bordering the United States of America

\begin{tabular}{|c|c|c|c|c|c|}
\hline Variable & $\begin{array}{l}\text { Lymph } \\
\text { node }\end{array}$ & Lung (s) & Liver & $\begin{array}{c}\text { Other } \\
\text { organs/tissues }\end{array}$ & $\begin{array}{c}\text { Composed } \\
\text { samples }\end{array}$ \\
\hline \multicolumn{6}{|l|}{ Cattle age } \\
\hline Calves & 20 & 1 & 1 & 0 & 1 \\
\hline Heifers/steers & 45 & 5 & 3 & 1 & 2 \\
\hline Adults & 347 & 17 & 4 & 9 & 36 \\
\hline \multicolumn{6}{|l|}{ Breed } \\
\hline Non-defined breed & 191 & 12 & 5 & 4 & 28 \\
\hline B. indicus & 78 & 3 & 1 & 4 & 8 \\
\hline B. taurus & 128 & 7 & 1 & 1 & 5 \\
\hline B. taurus $\mathrm{x}$ B. indicus & 50 & 1 & 1 & 3 & 3 \\
\hline \multicolumn{6}{|l|}{ Geographical origin } \\
\hline Northern municipalities & 76 & 9 & 4 & 6 & 8 \\
\hline Central municipalities & 88 & 3 & 0 & 1 & 7 \\
\hline Southern municipalities & 210 & 4 & 3 & 1 & 20 \\
\hline Southwest municipalities & 9 & 1 & 0 & 0 & 0 \\
\hline \multicolumn{6}{|l|}{ Type of slaughterhouse } \\
\hline Municipal & 322 & 22 & 11 & 12 & 39 \\
\hline Federal inspected & 152 & 4 & 0 & 0 & 9 \\
\hline Total & 492 & 26 & 11 & 13 & 57 \\
\hline
\end{tabular}

${ }^{1}$ Kidney, adipose tissue, salivary gland, thoracic wall, spleen, abdominal wall, small intestine, hearth.

Table 2. Prevalence and risk factors associated with bovine tuberculosis in cattle from the Northeast of Mexico, bordering the United States of America

\begin{tabular}{lccc}
\multicolumn{1}{c}{ Variable } & $\begin{array}{c}\text { Apparent prevalence } \\
(\%)\end{array}$ & $\begin{array}{c}\text { True } \\
\text { prevalence }\end{array}$ & $\begin{array}{c}\text { Odds ratio } \\
(\mathrm{P}<0.0001)\end{array}$ \\
\hline Cattle age & & & \\
Calves & 4.35 & 3.98 & 0.221 \\
Heifers/steers & 1.79 & 1.41 & 0.081 \\
Adults & 19.13 & 18.85 & 2.19 \\
Breed & & & \\
Non-defined breed & 8.33 & 7.99 & 0.362 \\
B. indicus & 10.64 & 10.31 & 0.64 \\
B. taurus & 22.54 & 22.28 & 2.135 \\
B. taurus x B. indicus & 29.31 & 29.09 & 2.769 \\
Geographical origin & & & \\
Northern municipalities & 8.74 & 8.4 & 0.32 \\
Central municipalities & 20.2 & 19.93 & 1.035 \\
Southern municipalities & 23.11 & 22.85 & 1.573 \\
Southwestern municipalities & 50.00 & 49.9 & 4.238 \\
Type of slaughterhouse & & & \\
Municipal & 14.78 & 14.48 & 0.813 \\
Federal inspected & 17.58 & 17.29 & 1.23 \\
\hline
\end{tabular}




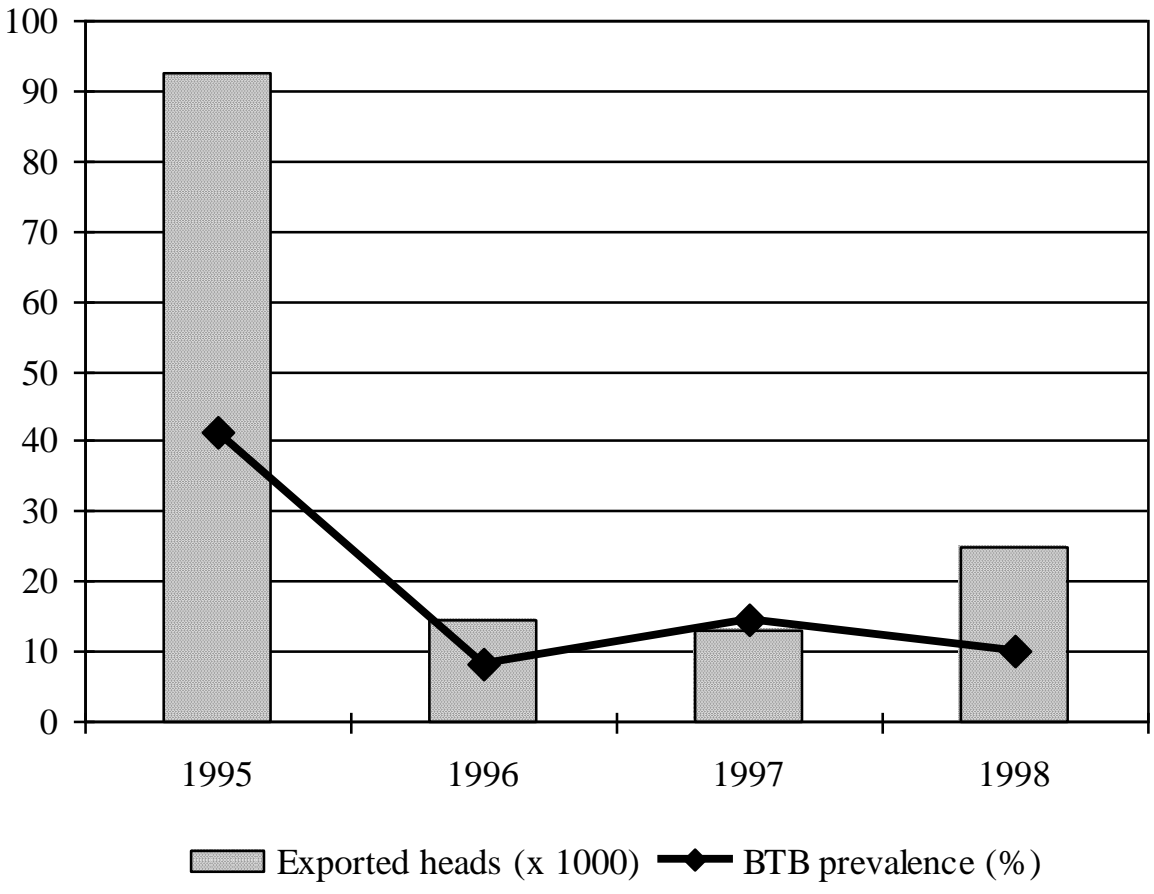

Figure 1. Relationship between the prevalence of bovine tuberculosis and exporting cattle to the United States of America in the state of Tamaulipas, Mexico.

\section{DISCUSSION}

BTB is a worldwide spread disease with public health implications and economic repercussions for local and international trade. Therefore, in 1992, the World Health Organization recommended that BTB should become a disease with mandatory notification (PAHO, 1992), after which programs for controlling and eradicating were implemented in several countries (Cousins, 2001). The success of these programs depends upon information concerning prevalence of this and other diseases (Acosta-Gonzalez et al., 2009). However, epidemiological surveys for BTB in Mexico are scarce. In spite of this, some studies have been carried out in this country.

Milian-Suazo et al. (2000) determined a prevalence of BTB in dairy cattle, for the period between 1996 and 1997, of 16\% and mainly of the positive animals were adult females with fair to good body condition scores. In 1996, a prevalence of $17 \%$ was reported for dairy cattle during slaughterhouse carcass inspection (Milián et al., 2000). The overall prevalence obtained in the present survey $(18.85 \%)$ was similar to the aforementioned, and despite this study was carried out on beef cattle, the results are in agreement with the officially reported BTB prevalence of $16 \%$ for dairy cattle in Mexico (Milián et al., 2000). Other authors have reported prevalence values considerably lower than those described in this study. In the Mexican state of Baja California, the prevalence of BTB in slaughtered cattle was of 0.12 and $0.46 \%$ for the years 1995 and 1996, respectively (Hernández de Anda et al., 1997). In addition, the prevalence of BTB in cattle from Tamaulipas that were exported to and slaughtered in Texas was of $1.81 \%$; in contrast, other Mexican states that border Texas had lower prevalence, i.e., Chihuahua $(0.07 \%)$, Coahuila $(0.8 \%)$, and Nuevo Leon $(1.27 \%)$. This prevalence from Mexican states could represent a risk for the BTBtransmission to Texan cattle (Brown and Hernández de Anda, 1998), despite the state of Texas had the most tuberculous cattle herds that any state in the United States in the decade of 1990 (Pillai et al., 2000).

The results of this study are comparable with the international situation concerning surveillance surveys of BTB at slaughterhouse level. Similar overall prevalence values have been reported for 
Ethiopia (10.2\%), where the disease was associated with the age, exotic breeds, type of slaughterhouse, and geographic origin of the animals (Demelash et al., 2009). However, the results here presented were lower than the reported $53.3 \%$ for slaughterhouses of Sudan (Sulieman, Hamid, 2002), but higher than the $3.85 \%$ reported for slaughterhouses from Ecuador (Proaño-Perez et al., 2006), $4.7 \%$ for Ethiopia (Berg et al., 2009), and 7.3\% in Chad (Diguimbaye-Djaibé et al., 2006).

The considerably higher prevalence for the year 1995 was expected because at that time, there were no activities focused in the control of BTB. After the reduction of the prevalence in 1996, there was a slightly rising of this pattern in subsequent years (1997 and 1998), which is consistent with the previously reported in other studies (PAHO, 1992; Tadayon et al., 2008; Demelash et al., 2009). The aforementioned increment is consequence of detecting as positive to skin test animals infected with other Mycobacterium spp. that do not belong to the tuberculosis complex, at the final stages of the eradication programs (Scacchia et al., 2000).

Regarding risk factors, the association between breed, specifically $B$. taurus genotypes, reported in this study, also has been reported by other authors (Kazwala et al., 2001; Ameni et al., 2007; Tadayon et al., 2008; Ngandolo et al., 2009). However, Elias et al. (2008) stated that the breed of cattle is not associated with BTB. Other reported factors associated with BTB are older animals (Kazwala et al., 2001; Ameni et al., 2007; Elias et al., 2008) and the geographical area where the cattle are located (Kazwala et al., 2001; Munyeme et al., 2009).

\section{CONCLUSIONS}

Although the risk factors identified in this study are in agreement with several studies, additional slaughterhouse surveys must be conducted for monitoring the prevalence of BTB for eradicating the disease. Furthermore, the Northern states of Mexico and the Southern states of the United States of America should continue with collaborative activities in order to achieve the free-status of BTB and maintain the livestock trade between both countries.

\section{ACKNOWLEDGEMENTS}

This paper is part of the Doctor in Veterinary Medicine degree thesis of the author Cesael Enríquez-Cruz. The study was supported by the Universidad Autónoma de Tamaulipas and Comité para el Fomento y Protección Pecuaria del Estado de Tamaulipas. The publication of this paper was supported in full by the Fondo Mixto de Fomento a la Investigación Científica y Tecnológica CONACYT - Gobierno del Estado de Tamaulipas (México).

\section{REFERENCES}

ACOSTA-GONZALEZ, R.I.; INFANTE, F.; FLORES-GUTIERREZ, G.H. Epidemiological patterns of caprine brucellosis in an unvaccinated area, Mexico. Rev. Med. Vet., v.160, p.145-148, 2009.

AMENI, G.; ASEFFA, A.; ENGERS, H. et al. High prevalence and increased severity of pathology of bovine tuberculosis in Holsteins compared to zebu breeds under field cattle husbandry in central Ethiopia. Clin. Vaccine Immunol., v.14, p.1356-1361, 2007.

BERG, S.; FIRDESSA, R.; HABTAMU, M. et al. The burden of mycobacterial disease in Ethiopian cattle: implications for public health. PLoS One., v.4, p.e5068, 2009

BROWN, W.H.; HERNÁNDEZ DE ANDA, J. Tuberculosis in adult beef cattle of Mexican origin shipped direct-to-slaughter into Texas. $J$. Am. Vet. Med. Assoc., v.212, p.557-559, 1998.

COUSINS, D.V. Mycobacterium bovis infection and control in domestic livestock. Rev. Sci. Tech., v.20, p71-85, 2001.

DEMELASH, B.; INANGOLET, F.; OLOYA, J. et al. Prevalence of bovine tuberculosis in Ethiopian slaughter cattle based on post-mortem examination. Trop. Anim. Health Prod., v.41, p.755-765, 2009.

DIGUIMBAYE-DJAIBÉ, C.; HILTY, M.; NGANDOLO, R. et al. Mycobacterium bovis isolates from tuberculous lesions in Chadian zebu carcasses. Emerg. Infect. Dis., v.12, p.769771, 2006. 
DOF. Norma Oficial Mexicana NOM-031-ZOO1995 Campaña nacional contra la tuberculosis bovina (Mycobacterium bovis). México: Diario Oficial, 1996. 28p.

ELIAS, K.; HUSSEIN, D.; ASSEGED, B. et al. Status of bovine tuberculosis in Addis Ababa dairy farms. Rev. Sci. Tech., v.27, p.915-923, 2008.

FITZGERALD, S.D.; KANEENE, J.B.; BUTLER, K.L. et al. Comparison of postmortem techniques for the detection of Mycobacterium bovis in white-tailed deer (Odocoileus virginianus). J. Vet. Diagn. Invest., v.12, p.322327, 2000.

HERNÁNDEZ DE ANDA， J.; RENTERÍA EVANGELISTA, T.; LÓPEZ VALENCIA, G. et al. An abattoir monitoring system for diagnosis of tuberculosis in cattle in Baja California, Mexico. J. Am. Vet. Med. Assoc., v.211, 709$711,1997$.

KAZWALA, R.R.; KAMBARAGE, D.M.; DABORN, C.J. et al. Risk factors associated with the occurrence of bovine tuberculosis in cattle in the Southern Highlands of Tanzania. Vet. Res. Commun., v.25, p.609-614, 2001.

MILIÁN, F.; SÁNCHEZ, L.M.; TOLEDO, P. et al. Descriptive study of human and bovine tuberculosis in Querétaro, México. Rev. Latinoam. Microbiol., v.42, p.13-19, 2000.

MILIAN-SUAZO, F.; SALMAN, M.D.; RAMIREZ, $C$. et al. Identification of tuberculosis in cattle slaughtered in Mexico. Am. J. Vet. Res., v.61, p.86-89, 2000.

MUNYEME, M.; MUMA, J.B.; SAMUI, K.L. et al. Prevalence of bovine tuberculosis and animal level risk factors for indigenous cattle under different grazing strategies in the livestock/wildlife interface areas of Zambia. Trop. Anim. Health Prod., v.41, p345-352, 2009.

NGANDOLO, B.N.; MÜLLER, B.; DIGUIMBAYE-DJAÏBE, C. et al. Comparative assessment of fluorescence polarization and tuberculin skin testing for the diagnosis of bovine tuberculosis in Chadian cattle. Prev. Vet. Med., v.89, p.81-89, 2009.
O'BRIEN, D.J.; SCHMITT, S.M. FITZGERALD, S.D. et al. Managing the wildlife reservoir of Mycobacterium bovis: the Michigan, USA, experience. Vet. Microbiol., v.112, p.313323, 2006.

OIE. Bovine tuberculosis. In: Terrestrial manual. Paris: World Organisation of Animal Health, 2008. Available in:

<http://www.oie.int/eng/normes/mmanual/2008/ pdf/2.04.07_BOVINE_TB.pdf $>$. Consulted in: 14 aug 2009.

PAHO (Pan American Health Organization. International meeting on the eradication of bovine tuberculosis in the Americas. Bull. Pan. Am. Health Organ., v.26, p.279-281, 1992.

PILLAI, S.D.; WIDMER, K.W.; IVEY, L.J. et al. Failure to identify non-bovine reservoirs of Mycobacterium bovis in a region with a history of infected dairy-cattle herds. Prev. Vet. Med., v.43, p.53-62, 2000.

PROAÑO-PEREZ, F.; RIGOUTS, L.; BRANDT, J. et al. Preliminary observations on Mycobacterium spp. in dairy cattle in Ecuador. Am. J. Trop. Med. Hyg., v.75, p.318-323, 2006.

ROADHOUSE, C.L. The prevalence of bovine tuberculosis. Cal. State J. Med., v.9, p.397-398, 1911.

SCACCHIA, M.; LELLI, R.; PETRINI, A. et al. Use of innovative methods in the eradication of bovine tuberculosis. J. Vet. Med. B Infect. Dis. Vet. Public Health., v.47, p.321-327, 2000.

SIAP (Servicio de Información Agroalimentaria y Pesquera). Exportación de ganado bovino en pie a los Estados Unidos de América, principales estados exportadores. México: Secretaría de Agricultura, Ganadería, Desarrollo Rural, Pesca y Alimentación, 2005. Available in: <http://www.siap.sagarpa.gob.mx/ventana.php?i $\mathrm{dLiga}=1252 \&$ tipo $=1>$. Consulted in: 8 jul. 2009 .

SULIEMAN, M.S.; HAMID, M.E. Identification of acid fast bacteria from caseous lesions in cattle in Sudan. J. Vet. Med. B Infect. Dis. Vet. Public Health., v.49, p.415-418, 2002.

TADAYON, K.; MOSAVARI, N.; SADEGHI, F. et al. Mycobacterium bovis infection in Holstein Friesian cattle, Iran. Emerg. Infect. Dis., v.14, p.1919-1921, 2008. 